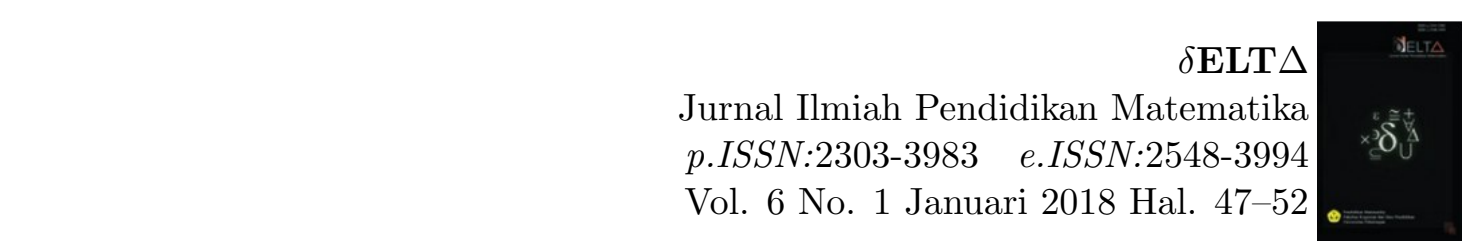

\title{
PENGARUH MODEL DISCOVERY LEARNING TERHADAP KEMAMPUAN KOMUNIKASI MATEMATIS DAN KEAKTIFAN BELAJAR SISWA SMP
}

\author{
Alfa Hida Maulida \\ Pendidikan Matematika Universitas Pekalongan \\ alfahida@gmail.com \\ Mitia Fatma Ningsih \\ Pendidikan Matematika Universitas Pekalongan \\ mitiafatmaningsih@yahoo.com \\ Titis BASTIAN \\ Pendidikan Matematika Universitas Pekalongan \\ titis.bastian@yahoo.co.id
}

\begin{abstract}
Abstrak
Kemampuan komunikasi matematis merupakan salah satu kemampuan yang harus dikuasai oleh siswa dalam pembelajaran matematika. Faktor lain yang perlu diperhatikan dalam pembelajaran matematika adalah keaktifan belajar siswa dalam mengikuti pembelajaran tersebut. Adapun tujuan dari artikel ini adalah untuk melihat bahwa ada pengaruh penggunaan model discovery learning terhadap kemampuan komunikasi matematis dan keaktifan belajar siswa dalam pembelajaran pada tingkat SMP. Dalam model discovery learning sendiri terdapat lima sintak yaitu stimulation, problem statement, data collection, data processing dan verification. Hasil kajian dalam artikel ini menunjukkan bahwa terdapat pengaruh penggunaan model discovery learning dalam mengembangkan kemampuan komunikasi matematis siswa, serta mampu meningkatkan keaktifan belajar siswa dalam pembelajaran matematika pada jenjang SMP.
\end{abstract}

Kata kunci: model discovery learning, kemampuan komunikasi matematis, keaktifan belajar

\begin{abstract}
Communication skill in mathematics is one ability that must be mastered by students in mathematics learning. Another factor that needs to be noticed in mathematics learning is student's activity. The aim of this article is to see wheter there is impact of the use of discovery learning model towards mathematics communication skill and students activity in junior high school grade. There are five steps in discovery learning model. They are stimulation, problem statement, data collection, data processing and verification. The result in this article shown that discovery learning model gives positive impact in communication in mathematics and activity of junior high school students.
\end{abstract}

Keywords: discovery learning model, communication skill, student activity

\section{Pendahuluan}

Pendidikan merupakan sumber daya yang sepatutnya mendapat perhatian terus menerus dalam upaya peningkatan mutunya. Peningkatan mutu pendidikan berarti pula meningkatkan kualitas sumber daya manusia. Untuk itu perlu dilakukan pembaruan dalam bidang pendidikan dari waktu ke waktu tanpa henti. Dalam rangka mencerdaskan kehidupan bangsa, maka peningkatan mutu pendidikan suatu hal yang sangat penting bagi 
pembangunan berkelanjutan di segala aspek kehidupan manusia. Sistem pendidikan nasional senantiasa harus dikembangkan sesuai dengan kebutuhan dan perkembangan yang terjadi baik di tingkat lokal, nasional, maupun global [Mulyasa, 2007, hal. 4].

Proses pembelajaran tersusun atas sejumlah komponen atau unsur yang saling berkaitan satu dengan lainnya. Interaksi antara guru dan siswa pada saat proses belajar mengajar memegang peran penting dalam mencapai tujuan yang diinginkan. Kemungkinan kegagalan guru dalam menyampaikan materi disebabkan saat proses belajar mengajar guru kurang membangkitkan perhatian dan aktivitas siswa dalam mengikuti pelajaran matematika. Adakalanya guru mengalami kesulitan untuk membuat siswa memahami materi yang disampaikan sehingga hasil belajar matematika rendah.

Keberhasilan pembelajaran matematika dapat diukur dari keberhasilan siswa yang mengikuti kegiatan pembelajaran tersebut. Keberhasilan itu dapat dilihat dari tingkat pemahaman, penguasaan materi, serta prestasi belajar siswa. Semakin tinggi pemahaman dan penguasaan materi serta prestasi belajar, maka semakin tinggi pula tingkat keberhasilan pembelajaran.

Dalam pembelajaran metematika,ada beberapa kemampuan yang harus dikuasai oleh peserta didik. Kemampuan- kemampuan tersebut diharapkan mampu secara menyeluruh dikuasai oleh peserta didik. Hal ini sesuai dengan tujuan pembelajaran matematika dalam kurikulum tingkat satuan pendidikan yaitu agar siswa mempunyai kemampuan untuk memahami konsep matematika, menggunakan penalaaran, memecahkan masalah, mengkomunikasikan gagasan dengan simbol, tabel, diagram, atau media lain untuk memperjelas keadaan atau masalah serta memiliki sikap menghargai kegunaan matematika dalam kehidupan BSNP, 2006.

National Counal of Teachers of Mathematichs menyatakan bahwa komunikasi matematika merupakan kemampuan mengorganisasi dan mengonsolidasi pikiran matematika melalui komunikasi secara lisan maupun tertulis, mengkomunikasikan gagasan tentang matematika secara logis dan jelas kepada orang lain, menganalisis dan mengevaluasi pikiran matematika dan strategi yang digunakan orang lain dan menggunakan bahasa matematika untuk menyatakan ide-ide matematika secara tepat [NCTM, 2000]. Hal ini menunjukkan kemampuan komunikasi dalam pembelajaran matematika merupakan hal yang sangat penting. Namun kemampuan matematis siswa di Indonesia berada pada level rendah. Hal ini dapat dilihat berdasarkan hasil Programme for International Student Assesment (PISA) tahun 2012, Indonesia hanya menduduki rangking 64 dari 65 peserta dan memperoleh skor 375.

Selain kemampuan komunikasi matematis, salah satu faktor lain yang mempengaruhi proses belajar peserta didik adalah keaktifan belajar siswa dalam proses pembelajaran. Keaktifan siswa dalam belajar matematika sangat mempengaruhi hasil belajarnya, apabila siswa memiliki tingkat keaktifan yang tinggi akan mempermudah siswa dalam memahami matematika dan akan meningkatkan hasil belajarnya.

Menurut beberapa permasalahan berkaitan dengan kemampuan komunikasi matematis dan keaktifan belajar siswa, mengharuskan guru menerapkan model pembelajaran yang sesuai sehingga tujuan dari pembelajaran dapat dicapai dengan baik. Model pembelajaran yang dapat mengasah kemampuan komunikasi matematis dan keaktifan belajar siswa adalah model pembelajaran discovery learning.

Model discovery learning adalah salah satu model pembelajaran yang berpusat pada siswa (student central learning) dimana model pembelajaran ini mengharuskan siswa aktif dalam pembelajaran. Discovery learning merupakan sebuah teori pembelajaran yang diartikan sebagai bentuk proses belajar yang terjadi jika siswa tidak disuguhkan dengan pelajaran dalam bentuk akhirnya, akan tetapi diharapkan untuk mengorganisasi sendiri. Suryosubroto dalam Siti Nur Halimah [Halimah, 2017] menyatakan bahwa metode discovery diartikan sebagai suatu prosedur mengajar yang mementingkan pengajaran, perseorangan, manipulasi objek dan lain-lain percobaan, sebelum sampai pada generalisasi. 
Dengan discovery peserta didik dapat mengembangkan cara belajar aktif, dengan menemukan dan menyelidiki sendiri konsep yang dipelajari, maka hasil yang diperoleh akan tahan lama dalam ingatan dan tidak mudah dilupakan oleh peserta didik.

Adapun tujuan dari penulisan artikel ini adalah penulis ingin menunjukkan bahwa terdapat pengaruh dalam penggunaan model discovery learning terhadap kemampuan komunikasi matematis dan keaktifan belajar siswa pada tingkat SMP.

\section{Kajian Teori}

\subsection{Model discovery learning}

Model discovery learning adalah salah satu model pembelajaran yang berpusat pada siswa (student central learning) dimana model pembelajaran ini mengharuskan siswa aktif dalam pembelajaran. Suryosubroto menyatakan bahwa metode discovery diartikan sebagai suatu prosedur mengajar yang mementingkan pengajaran, perseorangan, manipulasi objek dan lain-lain percobaan, sebelum sampai pada generalisasi Halimah, 2017. Menurut Syah Ai Halimatussadiah dan Leli Halimah terdapat enam langkah pembelajaran melalui metode discovery learning secara umum yaitu stimulasi, menyatakan masalah, pengumpulan data, pengolahan data, pembuktian, dan menarik kesimpulan Halimatussadiah and Halimah, 2017. Dengan discovery peserta didik dapat mengembangkan cara belajar aktif, dengan menemukan dan menyelidiki sendiri konsep yang dipelajari, maka hasil yang diperoleh akan tahan lama dalam ingatan dan tidak mudah dilupakan oleh peserta didik. Adapun tahapan discovery learning yaitu :

1. Tahap stimulation (pemberian rangsangan)

Sebelum pembelajaran di mulai yaitu siswa di hadapkan pada sesuatu yang menimbulkan tanda tanya, kemudian dilanjutkan untuk tidak memberi generalisasi, agar timbul keinginan untuk menyelidiki sendiri serta dapat mengembangkan dan membantu siswa dalam mengekplorasi bahan.

2. Tahap statement (identifikasi masalah)

Guru memberi kesempatan kepada siswa untuk mengidentifikasi sebanyak mungkin masalah yang relevan dengan bahan pelajaran, kemudian salah satunya dipilih dan dirumuskan dalam bentuk pertanyaan, atau hipotesis, yakni pertanyaan sebagai jawaban sementara atas pertanyaan yang diajukan.

3. Tahap data collection (pengumpulan data)

Ketika eksplorasi berlangsung guru juga memberi kesempatan kepada siswa untuk mengumpulkan informasi sebanyak-banyaknya yang relevan untuk membuktikan benar atau tidaknya hipotesis.

4. Tahap data processing (pengolahan data)

Kegiatan mengolah data dan informasi yang telah diperoleh siswa baik melalui wawancara, observasi dan sebagainya lalu ditafsirkan.

5. Tahap verification (pembuktian)

Siswa melakukan pemeriksaan secara cermat untuk membuktikan benar atau tidaknya hipotesis yang ditetapkan dengan temuan alternatif, dihubungkan dengan temuan lainnya.

6. Tahap generalization (menarik kesimpulan)

Sebuah tahapan yang dilakukan oleh peserta didik untuk menarik sebuah kesimpulan yang dijadikan sebagai prinsip umum.

Metode discovery learning didukung oleh teori John Dewey, Piaget, Vygotsky, dan Bruner. Kaitannya dengan teori John Dewey yakni siswa diberikan kesempatan untuk menyatakan masalah melakukan penyelidikan sehingga termotivasi untuk belajar. 


\subsection{Kemampuan komunikasi matematis}

Komunikasi matematis merupakan suatu cara peserta didik untuk mengungkapkan ide-ide matematis mereka baik secara lisan, tertulis, gambar, diagram menggunakan benda, menyajikan dalam bentuk aljabar, atau menggunakan simbol matematika NCTM, 2000, hal. 60]. Kemampuan komunikasi matematis mempengaruhi kemampuan matematis yang lain, seperti kemampuan pemecahan masalah. Hal tersebut sejalan dengan Aprilia Halimah, 2017 yang berpendapat bahwa kemampuan komunikasi matematis merupakan kemampuan peserta didik dalam hal menjelaskan suatu algoritma dan cara unik untuk pemecahan masalah, kemampuan peserta didik mengkonstruksi dan menjelaskan sajian fenomena dunia nyata secara grafik, kata-kata/kalimat, persamaan, tabel dan sajian secara fisik. Kemampuan komunikasi matematis merupakan salah satu kemampuan yang perlu dikembangkan dalam pembelajaran matematika menurut NCTM [NCTM, 2000].

Kemampuan komunikasi matematis dapat dilihat dari beberapa aspek. Menurut NCTM kemampuan komunikasi matematis dapat dilihat dari kemampuan:

1. mengorganisasi dan mengkonsolidasi ide matematis melalui komunikasi,

2. mengkomunikasikan ide matematis secara logis dan jelas kepada teman, guru, dan lainnya,

3. menganalisis dan mengevaluasi ide matematis dan strategi lain, menggunakan bahasa matematika untuk menyatakan ide matematis secara tepat.

Selain aspek-aspek menurut NCTM tersebut, Sumarmo Halimah, 2017 mengemukakan beberapa indikator kemampuan komunikasi matematis, yang meliputi: (1) menghubungkan benda nyata, gambar, dan diagram ke dalam ide matematika; (2) menjelaskan ide, situasi, dan relasi matematis secara lisan atau tulisan dengan benda nyata, gambar, grafik, dan aljabar;(3) menyatakan peristiwa sehari-hari dalam bahasa atau simbol matematika; (4) mendengarkan, berdiskusi, dan menulis tentang matematika; (5) membaca dengan pemahaman suatu presentasi matematika tertulis; (6) membuat konjektur, menyusun argumen, merumuskan definisi, dan generalisasi; dan (7) menjelaskan dan membuat pertanyaan tentang matematika yang telah dipelajari.

Indikator kemampuan komunikasi lisan meliputi: menjelaskan kesimpulan yang diperoleh; menafsirkan solusi yang diperoleh; memilih cara yang paling tepat dalam menyampaikan penjelasannya; menggunakan tabel, gambar, model, dan lain-lain untuk menyampaikan penjelasan; mengajukan suatu permasalahan atau persoalan; menyajikan penyelesaian dari suatu permasalahan; merespon suatu pertanyaan atau persoalan dari siswa lain dalam bentuk argumen yang meyakinkan; menginterpretasi dan mengevaluasi ideide, simbol, istilah, serta informasi matematika; serta mengungkapkan lambang, notasi, dan persamaan matematika secara lengkap dan benar [Halimah, 2017]. Sedangkan indikator kemampuan komunikasi tertulis dikemukakan oleh Ross dalam Siti Nur Halimah Halimah, 2017 adalah: menggambarkan situasi masalah dan menyatakan solusi masalah menggunakan gambar, bagan, tabel, atau penyajian secara aljabar; menyatakan hasil dalam bentuk tulisan; menggunakan representasi menyeluruh untuk menyatakan konsep matematika dan solusinya; membuat situasi matematika dengan menyediakan ide dan keterangan dalam bentuk tulisan; serta menggunakan bahasa matematika dan simbol secara tepat. Komunikasi matematika lisan berdasarkan aktivitas lisan selama pembelajaran dan komunikasi matematika tertulis yaitu komunikasi melalui tulisan.

\subsection{Keaktifan belajar}

Keaktifan adalah kegiatan yang bersifat fisik maupun mental, yaitu berbuat dan berfikir sebagai suatu rangkaian yang tidak dapat dipisahkan Sardiman, 2000. Belajar yang berhasil harus melalui berbagai macam aktifitas, baik aktifitas fisik maupun 
psikis. Aktifitas fisik adalah siswa giat aktif dengan anggota badan, membuat sesuatu, bermain maupun bekerja, ia tidak hanya duduk dan mendengarkan, melihat atau hanya pasif. Siswa yang memiliki aktifitas psikis (kejiwaan) adalah jika daya jiwanya bekerja sebanyakbanyaknya atau banyak berfungsi dalam rangka pembelajaran. Menurut Rusman, kunci keberhasilan pencapaian tujuan pembelajaran juga terletak pada keaktifan belajar siswa dalam proses pembelajaran Sari, 2016. Sedangkan Gulo, mengungkapkan bahwa pembelajaran menjadikan siswa sebagai subyek yang aktif dalam proses pembelajaran dan bukan lagi obyek pembelajaran Sari, 2016. Hamalik juga menyatakan bahwa pembelajaran menekankan pada keaktifan siswa dalam proses pembelajaran [Sari, 2016].

\section{Hasil dan Pembahasan}

Komunikasi matematis merupakan kemampuan peserta didik dalam hal menjelaskan suatu algoritma dan cara unik untuk pemecahan masalah, kemampuan peserta didik mengkonstruksi dan menjelaskan sajian fenomena dunia nyata secara grafik, kata-kata atau kalimat, persamaan, tabel dan sajian secara fisik. Keaktifan siswa dalam kegiatan belajar tidak lain adalah untuk mengkonstruksi pengetahuan mereka sendiri. Mereka aktif membangun pemahaman atas persoalan atau segala sesuatu yang mereka hadapi dalam proses pembelajaran. Prinsip keaktifan mengemukakan bahwa individu merupakan manusia belajar yang aktif selalu ingin tahu, dalam hal ini Segala pengetahuan harus diperoleh dengan pengamatan sendiri, pengalaman sendiri, penyelidikan sendiri, dengan bekerja sendiri dengan fasilitas yang diciptakan sendiri, baik secara rohani maupun teknik. Berdasarkan kajian teori yang kami peroleh bahwa model discovery learning dapat meningkatkan kemampuan komunikasi matematis siswa, serta mampu meningkatkan keaktifan belajar siswa dalam pembelajaran matematika pada jenjang SMP.

\section{Simpulan}

Model discovery learning adalah salah satu model pembelajaran yang berpusat pada siswa (student central learning) dimana model pembelajaran ini mengharuskan siswa aktif dalam pembelajaran. Dengan discovery peserta didik dapat mengembangkan cara belajar aktif, dengan menemukan dan menyelidiki sendiri konsep yang dipelajari, maka hasil yang diperoleh akan tahan lama dalam ingatan dan tidak mudah dilupakan oleh peserta didik. Dalam hal ini Komunikasi matematis merupakan suatu cara peserta didik untuk mengungkapkan ide-ide matematis mereka baik secara lisan, tertulis, gambar, diagram, menggunakan benda, menyajikan dalam bentuk aljabar, atau menggunakan simbol matematika. Kemampuan komunikasi matematis mempengaruhi kemampuan matematis yang lain, seperti kemampuan pemecahan masalah. Setelah peserta didik menguasai kemampuan matematis dalam pemecahan masalah yang dihadapi, peseerta didik diwajibkan meningkatkan keaktifan balajar siswa, dalam hal ini kegiatan yang bersifat fisik maupun mental, yaitu berbuat dan berfikir sebagai suatu rangkaian yang tidak dapat dipisahkan. Belajar yang berhasil harus melalui berbagai macam aktifitas, baik aktifitas fisik maupun psikis. Aktifitas fisik adalah siswa giat aktif dengan anggota badan, membuat sesuatu, bermain maupun bekerja, ia tidak hanya duduk dan mendengarkan, melihat atau hanya pasif. Siswa yang memiliki aktifitas psikis (kejiwaan) adalah jika daya jiwanya bekerja sebanyakbanyaknya atau banyak berfungsi dalam rangka pembelajaran. Keaktifan siswa dalam kegiatan belajar tidak lain adalah untuk mengkonstruksi pengetahuan mereka sendiri. Prinsip keaktifan mengemukakan bahwa individu merupakan manusia belajar yang aktif selalu ingin tahu Segala pengetahuan harus diperoleh dengan pengamatan sendiri, pengalaman sendiri, penyelidikan sendiri, dengan bekerja sendiri dengan fasilitas yang diciptakan sendiri, baik secara rohani maupun teknik. 


\section{Referensi}

[BSNP, 2006] BSNP (2006). Kurikulum tingkat satuan pendidikan. Jakarta: Departemen Pendidikan Nasional.

[Halimah, 2017] Halimah, S. N. (2017). Meningkatkan kemampuan komunikasi matematik siswa smp menggunakan pendekatan discovery learning berbantuan software geogebra.

[Halimatussadiah and Halimah, 2017] Halimatussadiah, A. and Halimah, L. (2017). Efektivitas pembelajaran metode discovery learning terhadap kemampuan komunikasi matematis. Antologi UPI, 5:35-43.

[Mulyasa, 2007] Mulyasa, E. (2007). Kurikulum tingkat satuan pendidikan sebuah panduan praktis. Bandung: PT Remaja Rosdakarya.

[NCTM, 2000] NCTM (2000). Principles and standards for school mathematics, volume 1. National Council of Teachers of Mathematics.

[Sardiman, 2000] Sardiman, A. M. (2000). Interaksi \& motivasi belajar mengajar. PT Raja Grafindo Persada.

[Sari, 2016] Sari, D. N. (2016). Pengaruh penggunaan dicsovery learning dengan scramble terhadap keaktifan belajar dan hasil belajar matematika bagi siswa kelas viii smp n 1 karanggede kabupaten boyolali semester ii tahun pelajaran 2015/2016. 